\title{
Tegn og deiksis
}

\author{
Ole Togeby
}

\begin{abstract}
Five theses about sign systems and articulation: It is shown that although most sign systems with single articulation (mathematics, predicate logic and sheets of music) lack deictic reference, the artificial language $R_{0}$ has deixis. Double articulation of natural languages gives redundancy necessary for the performance in real time of the messages. In general, meaning is to be anchored to rhetorical situation, but mathematics and logic is not anchored and the meaning is consequently always generic. Natural sign systems have four types of meaning that are metacommunication of each other: conceptual meaning, propositional meaning, informational meaning and interactional meaning.
\end{abstract}

Nøgleord: deiksis, tegnsystemers artikulation, redundans, naturlige sprog, matematik

\section{Deiksis og artikulation}

Grundlaget for denne artikel er det foredrag som jeg holdt på grammatiknetværksmødet i København 28/10 2016, hvori jeg argumenterede for at årsagen til at deiksis, som i ordene jeg, $d u$, her, nu, kun findes i naturlige sprog, er at de er dobbeltartikulerede. Jeg er så i diskussionerne og fagfællebedømmelsen blevet overbevist om at denne tese ikke holder. I artiklen vil jeg så i stedet undersøge hvorfor naturlige sprog er dobbeltartikulerede, og hvad der er det særlige ved deiktiske størrelser i forhold til den implicitte forankring til den retoriske situation som fast placerede tegn har og vilkårligt placerede tegn ikke har. Argumenterne vil forløbe i fem trin:

I. Tesen om at eksplicit sproglig deiksis kun findes i naturlige sprog fordi de som tegnsystemer er dobbeltartikulerede, viser sig ikke at 
være holdbar. Kunstsproget ro er et enkelt-artikuleret tegnsystem der har deiksis, selv om andre enkeltartikulerede tegnsystemer ikke har.

II. Enkeltartikulerede tegnsystemer (matematik, formel logik og noder) er både konstruerede og visuelle (grafiske); de kan ikke processeres lydligt og auditivt i virkelig tid, sådan som det dobbeltartikulerede naturlige sprog kan. Dobbeltartikulationen giver nemlig den redundans der er nødvendig for at mennesker kan producere og interpretere ytringer i virkelig tid.

III. Deiktiske ord i visuelle tegn der ikke er forankret i tid og rum, fungerer ikke. En flaskepost med Kom og frels mig! Jeg befinder mig $i$ dag lige her kan ikke tolkes. Visuelle tegn der ved fast placering af tegnets form har forudsat situationel forankring, kan derimod godt give deiktisk mening, fx cyklistens højresvingsarm, færdselsskilte og piktogrammer. Den deiktiske mening er her ikke eksplicit, men implicit og forudsat.

Denne situationelle forankring af tegnets form, er ikke blot et naturligt 'tegn på' (dvs. virkningen af eller symptomet på) tegnets produktion, men en del af tegnets mærkbare form som er produceret af tegngiveren med refleksiv intention.

IV. Grunden til at matematik og formel logik hverken har deiksis eller homonymi, er at de som formelle sprog er født skriftlige, og dermed er uden forudsat situationel forankring, at de er ren syntaks uden semanik, og at de, som også nodeskrift, kun har generisk mening.

V. I naturlige sprog kommer den interaktionelle mening (tegngiverens hensigt) før den informationelle mening (relevansen for adressaterne), som kommer før den propositionelle mening (om sandhedsværdien af udsagnet om den fremstillede situation), som kommer før den konceptuelle mening (om det generiske sagforhold). 


\section{Enkeltartikulerede tegnsystemer kan godt have deiksis}

Deiktiske elementer i sproget er morfemer der henviser til tid, sted eller personer i den retoriske situation. I modsætning til semantiske morfemer som hest, stor og løbe, der henviser til generelle begreber, henviser de til specifikke ting, og i modsætning til pronominer som hun, ham, den, der også henviser specifikt, men som skifter betydning hen igennem en tekst og ved anaforisk henvisning udpeger et element i den fremstillede situation som er beskrevet sidst, udpeger de stabilt gennem en hel tekst elementer i den aktuelle retoriske situation. Deiktiske morfemer henviser til den retoriske situations personer: jeg, $d u$ (i alle bøjningsformer), steder: her, der og tider: nu, om lidt, for lidt siden, $i$ går og mange flere, og verbernes tempusbøjning -er, -ede. Deiktiske størrelser findes i alle danske sætninger (med tidsbøjede verber) og i alle naturlige sprog, men ikke i matematik, formel logik eller i nodeskrift.

I mit foredrag prøvede jeg at undersøge den tese at årsagen til at deiktiske morfemer findes i naturlige sprog, men ikke i andre tegnsystemer, er at de er dobbeltartikulerede, i modsætning til matematik, formel logik og nodeskrift, som er enkelt artikulerede.

Artikulation betyder leddeling. Den kan være vertikalt betydningsalternativer i koden (Jacobson 1967), fx skellet mellem cifrene i matematikken: 1, 2, 3 ..., og mellem substantiver i paradigmet: kvinde, mand, pige, dreng. Den vertikale artikulation resulterer i et inventar af mindstetegn, en ordbog som skal kendes af tegnbrugerne. Artikulationen kan også være horisontal som kombination af sekvenser i kæden, fx i syntagmer af tal og regnetegn i en ligning: $9+$ $16=25$, eller i syntaktiske led i en sætning: koinde-n mod-te mand-en. Billeder har ingen artikulation; der er hverken leddeling eller paradigmer af mulige alternativer i et billede. Matematik, prædikatslogik og nodeskrift og sprog er på denne måde artikulerede.

Men naturlige sprog har dobbelt artikulation, både vertikalt og horisontalt: en sætning kan inddeles i enheder som hver har deres paradigmer, sætningsled, som kan inddeles i ord, som kan inddeles i mindstetegn (morfemer) som har hele ordforrådet som inventar. Det er den ene artikulation. Men morfemer kan igen inddeles i enheder, som har deres inventar: 28 grafemer (bogstaver) eller ca. 40 fonemer. 
Det danske skriftsprog fungerer på den måde at systemet af ord (morfeminventaret) og systemet af bogstaver (bogstavinventaret) ikke har noget systematisk med hinanden at gøre. Man kan krybe i ly i en by, men man kan ikke krybe i lae bag en be. Fonemer angiver ikke noget andet end sig selv.

Det kan utvetydigt vises at deiksis ikke har noget med dobbeltartikulation at gøre, for der findes enkeltartikulerede tegnsystemer som har deiksis. Amerikaneren Edward P. Forster fik i første tredjedel af 1900-tallet den ide at man kunne konstruere et kunstigt sprog uden dobbelt bogholderi og med korte ord og sætninger, blot man indrettede sproget lige som det matematiske (syntaktiske) decimalsystem.

Forster konstruerede kunstsproget ro, hvor duc betyder 'top', dic 'op', dum betyder 'bund', dim 'ned'. Meningsmodsætningen mellem $u$ og $i$ er den samme. Hvert bogstav har altså sin betydningskomponent og er dermed mindstetegn som kan kombineres morfologisk og syntaktisk. Hvis man så lader det andet bogstav i et ord modificere det førstes betydning, kan man med brug af ord på op til kun 5 bogstaver fra et inventar på 25 bogstaver få udtrykt over 200.000 ordbetydninger.

Tanken er i virkeligheden ikke så tosset. Vi kender den fra 20 spørgsmål til professoren: Verden kan inddeles i planterige, dyrerige, mineralrige eller begreb. Vi kender det også fra decimalklassedelingssystemet på vores biblioteker. Under 01,6 står fagbibliografier, under 57. står botanik, og under 01,657 står fagbibliografier om botanik. Og man finder det også i en begrebsordbog eller tesaurus.

En tekst med flere sætninger på sproget ro kunne så komme til at se således ud: Abze radapav el in suda, ace rokab eco sugem, ace rajda ec kep, ace va eco, uz in suda asi in buba. Ingen ord er over fem bogstaver og alligevel er meningen intakt. Meningen afsløres senere.

Foster $(1908,1910)$ foreslog i to skrifter (og systemet ændrede sig stadig gennem de næste 20 år) følgende begrebslige decimalklassifikationssystem i koden med tilhørende regler for morfologi og syntaks i kæden: 
En initial vokal angiver ordklassen således:
Ordklasser
Eksempler
a- PRONOMINER
$a b-\mathrm{jeg}, a c-\mathrm{du}$
e- VERBER
eba- være, $e l$ - er
i-PRÆPOSITIONER
in - i, iz - blandt

En initial konsonant angiver kategorien således:

Kategorier
b- TING (SUBSTANSER)
c- KVANTITET
f- FORM
...

Eksempler

babac - ilt, bacra - ler

cafab - beløb, calif - meget

fabel - synes, fagam - portræt

Hver af disse kategorier kan så underinddeles ved at den efterfølgende vokal modificerer meningen, fx i et par af kategorierne således:

Underkategorier

ba TING (SUBSTANSER)

be FORM AF ET MATERIALE

bi HIMMEL, VEJR
Eksempler

babnac - ilt, bacra - ler

bed - væske, bejab - pulver

bidab - vind, bigal - regn

Og dernæst bruges resten af bogstavpladserne og alfabetet til at betegne forskellige andre grammatiske forhold. Der er så kun tilbage med resten af bogstaverne i fembogstavsordene at fastlægge det af de enkelte ords betydning som måtte mangle efter de 3 første bogstaver så det kan læses i en ordbog. Eksempel: Ord med konsonanterne $m$ - $l$ betegner det vegetative (l) liv i dyr (m) (herunder mennesket). I ordbogen kan man så finde: mala: 'ånde', male: 'drikke', muli: 'mad', molid: 'tand', molif: 'mund', molim: 'mave', malim: 'fordøje'.

Og her kommer så oversættelse af ro-teksten: Vor fader, som er i himlen, dit navn blive helliget, dit rige komme, din vilje ske, som i himlen således påjorden. Men ser at det første ord, abze, er deiktisk: $a$ (PRONOMEN) $b$ (1.PERSON) $+z$ (FLERTAL) + $e($ GENITIV $)=$ 'vor'. Enkeltartikulerede tegnsystemer kan altså have deiksis. Min hypotese er fuldstændig falsificeret. 


\section{Dobbeltartikulering giver redundans og mening}

Selv om Foster arbejdede ihærdigt i 25 år på at konstruere dette sprog med enkeltartikulation og ændrede dets fundamentale dele flere gange, kom det aldrig til at fungere, og der har næppe nogen sinde været kommunikeret for alvor ved hjælp af det.

Der er flere grunde til at sproget ro ikke kan bruges til kommunikation: Der er for lidt redundans, og der er for få kreative muligheder for ny mening. Vi har brug for redundans i sproget således at det kan fungere "in real time". Vores hjerne kan ganske simpelt ikke processere informationerne så hurtigt som det skal ske hvis man skal opfatte mening med hvert enkelt bogstav, eller i tale med hvert enkelt fonem. Et enkeltartikuleret sprog ville også være lige så skørt som glas og hele meningen ville gå tabt med blot en enkelt trykfejl eller fejlhøring på grund af støj.

Et dobbeltartikuleret naturligt sprog har en meget høj grad af redundans. Denne redundans ligger dels i rækken af fonemer eller bogstaver, dels i de begrænsede muligheder for kombination af morfemer til sætninger. Fonem og bogstavredundansen ses af følgende:

$$
\begin{aligned}
& M n k n g d t l s n \text { tkst } d r \text { r skrvt } d n v k l \text {, } \\
& \text { e e e æ uui a æe e e e e ee ue ooae }
\end{aligned}
$$

Man kan godt alene på grund af bogstavsredundansen læse at der i den første sætning står Man kan godt lese en tekst der er skrevet uden vokaler (som udgør godt 1/3 af de løbende bogstaver), men man kan kun til nød (og måske på grund af den retoriske redundans ved syntaktisk parallelisme og meningsmæssig modsætning) gætte at der i den anden sætning står men det er nesten umuligt at lase en tekst der er skrevet uden konsonanter (som udgør ca. 2/3 af bogstaverne). Arabisk skrives da også uden vokaler og kan læses af mange som ikke udtaler ordene ens, fx Abraham og Ibrahim, Fahve og Fehova.

At matematik med enkeltartikulation og dermed ingen redundans, kan fungere som tegnsystem, skyldes det at matematiske ligninger ikke bruges til live kommunikation mellem menesker i virkelig tid af en fremstillet situation, men til produktion for evigheden af strenge af skrifttegn der kan genereres efter regler, eller bevises som sande per definition. Matematik skal, fordi det er grafiske tegn, ikke kommunikere 'in real time', og overfødighed er derfor ikke nødvendigt. Men hvis man skal udtale matematik, dvs. hvis man læser ligninger op, kommunikeres det med et tegnsystem med dobbelt 
artikulation: de syv matematisk mindstetegn i $9+16=25$ udtrykkes med ca. 30 fonemer: ni plus seksten er lig med femogtyve.

Projektet med sproget ro mislykkedes for det andet fordi man ikke kan dele alt hvad vi vil sige om verden op efter et decimalklassifikationssystem. Tallegemet og den diatoniske musik er endimensionale meningsuniverser. Men vores verdensbillede er multidimensionalt, så på tredje decimal betyder samme bogstav ikke det samme i to ord (hvad cifrene i tallene og noderne jo faktisk gør). En vigtig grund til at man ikke kan have et enkeltartikuleret talesprog som ro, er de udtrykte og kommunikerede meningers manglende mangfoldighed. Det som enkeltartikulerede matematiske ligninger og formel logik er om, er altid tallenes størrelse og ligningernes velformethed, dvs. om de er tautologier med sandhedsværdi per definition. Den eneste mening man skal kunne opfatte ved læsning af matematiske tegn er om et tal kommer efter et andet i talrækken. Ganske vist er der uendeligt mange tal, men de ligger alle sammen på den samme dimension. Man ved altid hvilken kategori meningens elementer hører til. Matematikkens fremstillede verden er i den forstand endimensional.

Det samme gælder nodenotationen af musik; der er kun mening på en dimension, nemlig den diatoniske toneskala. Der findes mange syntaktiske regler om rene og falske toner, om harmoniske og uharmoniske klange og om tegnets (melodiens) begyndelse, midte og slutning, men det regulerede er ikke andet end notation af (vestlig) musik.

Naturlige sprog kan (vertikalt) artikulere semantiske modsætninger på uendeligt mange dimensioner; og hvis der ikke findes ord for at udtrykke noget nyt, kan almindelige sprogbrugere i sproglige tekster lave nye ord, $\mathrm{xx} p c$, smiley, sociale medier, opdatering og lave metaforer der bryder de syntaktiske og semantiske regler i sproget, til at udtrykke aldrig for kommunikerede tanker, metaforer fx (syntaktisk) flytning, government and binding.

Mens hovedfunktionen af naturlige talesprogs tegnsystemer er at være redskab til kommunikation, er hovedfunktionen for det matematiske tegnsystem og den formelle logik at være redskab til tænkning, en forlængelse af hukommelsen. 


\section{Mening skal forankres}

Ved visuelle tegn uden fast placering (billeder, skrift, matematik, noder) kan udsigelse og interpretation være adskilt i tid og rum. Tegntolkerne har dermed ikke, som ved gestus og tale, automatisk kendskab til tid og sted for tegnets produktion, og eksplicit deiksis kan derfor ikke fungere. En flaskepost med Kom og frels mig! Jeg befinder mig i dag lige her fungerer bare ikke.

I sådanne tekster må tegngiveren forankre tekstens produktion ved konventionelle henvisninger til årstal og geografiske adresser. Man kan angive udsigelsens tid, sted og personer i breve og dagbøger med datering og underskrift: Arhus 14. april 2017, i aviser, og bøger ved kolofoner, på nettet med hjemmesideadresser.

Visuelle tegnformer som tegngiveren giver fast placering, kan godt have deiktisk mening, for da forudsætter placeringen af de eksplicitte tegn at den fremstillede situation er den samme som interpretationssituationen (Togeby 2016).

2)
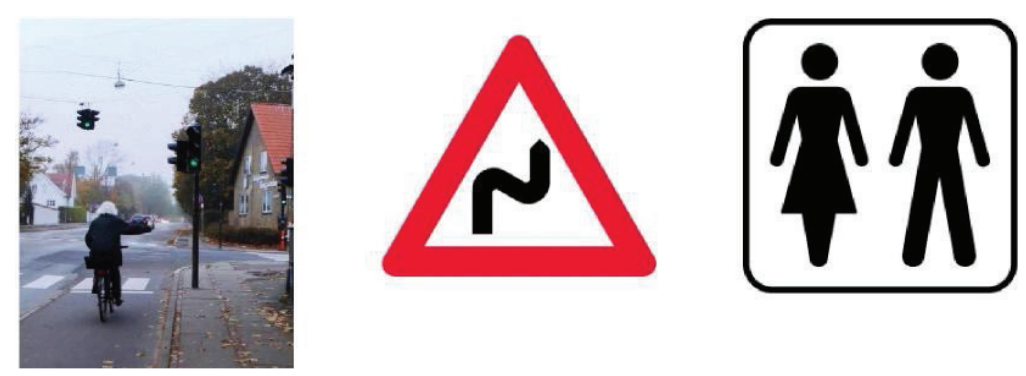

Når en cyklist rækker sin arm ud, er meningen (med den deiktiske mening understreget): 'Jeg drejer til højre om lidt'; trafikskiltet der står ved siden af vejen betyder: 'Du møder to sving om lidt'; og piktogrammet angiver: 'Der er unisextoiletter lige fremad for dig'. Den deiktiske mening er ikke angivet ved særlige explicitte bemærkelsesværdige (saliente) former, men tegngiveren har ved at give tegnets form en fast placering, forudsat (præsupponeret) at meningen er situationelt forankret til situationen hvor tegnet tolkes. Armen sidder på cyklisten, skiltet er sat op på et bestemt sted på vejen og piktogrammet er placeret lige over eller foran døren ind til toilettet.

Mod denne analyse kan man indvende at alle artefakter er naturlige 'tegn på' hvordan de er lavet. Alt hvad der kaldes tegn, har det som Grice 
(1957) kalder naturlig mening, og som Peirce (1994) kalder indeksikalsk mening, dvs. tegnets form er symptom på og virkning af hvad der har skabt den. Når et barn har røde pletter er det symptom på mæslinger, når en person gaber, er det et symptom på at hun er søvnig; når der kommer røg af en skorsten, er det tegn på at der er ild i komfuret eller kaminen. Naturlige tegn på noget er således ikke andet end at en betragter forstår årsagerne til visse formers forekomst i en situation, og der behøver ikke at være nogen tegngiver eller nogen kommunikation.

Kommunikative tegn er, i modsætning til naturlige tegn, tegn for noget. De involverer udover den naturlige mening det som Grice beskriver ved begrebet non-natural meaning, som han noterer mean ${ }_{\mathcal{N N}}$ : produce some effect in an audience by means of the recognition of this intention".

Kommunikative tegn forudsætter således intention fra tegngiverens side og intention fra tegntolkernes side om at aflæse tegngiverens intention, så tegntolkerne forstår tegnets mening gennem deres forståelse af tegngiverens hensigt. Hvis man ser ikke-naturlig mening fra tegntolkernes synsvinkel, må man beskrive det som (Tomasello 2003):

'Du har til hensigt [at jeg skal dele din opmærksomhed på [X]]'

Kommunikative tegn der fungerer som middel til kommunikation mellem mennesker, har altid denne ikke-naturlige, refleksive intention som tegngiveren i alle tre nævnte eksempler på deiksis også har i og med den faste placering af tegnets form.

Den gestus at en cyklist rækker højre arm ud som advarsel om sit snarlige højresving, er ikke blot symptom på hendes hensigt, men er også en advarsel med refleksiv intention. En højrearm strakt ud til siden signalerer nemlig kun snarligt højresving når den sidder på en cyklist der er trafikant på kørebanen. Det at en mand der står på fortovet, udstrækker højre arm, tæller ikke som snarligt højresving, og det at en betjent der står midt i et kryds og rækker højre arm ud, er et påbud til at de modkørende skal dreje til venstre. Medtrafikanterne må forstå at cyklisten har den hensigt at de skal opfatte noget fordi det opfatter at hun som cyklist og medtrafikant har denne hensigt. 
På samme måde vil et færdselsskilt med sin placering angive at tegngiveren (de kommunale trafikmyndigheder) har den hensigt at tegntolkerne (de modkørende trafikanter) skal forstå at de snarligt vil møde to vejsving, fordi de indser at skiltet er stillet op i den hensigt. Et piktogram angiver hvor toilettet er fordi man forstår at det er sat op for at vise det.

Meningen med en meddelelse hænger således uløseligt sammen med hvordan den fremstillede situation relateres til den retoriske situation, og hvordan den retoriske situation forankres. Der er fem måder det kan ske på: 1. implicit og forudsat forankring af den fremstillede situation til tegntolkningens tid og sted, 2. henvisning med eksplicitte og konventionelle deiktiske former til elementer i den retoriske situation (hvilket forudsætter 1.), 3. konventionel henvisning til historiske og geografiske begivenheder, tider, steder og personer som står i et velkendt forhold til den retoriske situation, 4. der er ingen opfattelig relation, og 5. forankring på skrømt, nemlig i fiktion.

1. Implicit og forudsat forankring. Den retoriske situation er forudsat som et implicit anker for tegnets mening som derved bliver situationel. Det gælder alle tegn med fast placering af tegnets form i forhold til den retoriske situations tid, sted og personer: gestus og tale, hvor tegngiverens udsigelse og tegntolkernes interpretation af tegnenes former finder sted i samme situation, nemlig den retoriske situation, men også trafikskilte og piktogramskilte, som med hensigt er fast placeret så de angiver at den fremstillede situation er den hvor tegntolkerne perciperer tegnenes former.

2. Eksplicit konventionel deiksis. Den fremstillede situation indgår i den retoriske situation fordi der med eksplicitte konventionelle deiktiske morfemtegn (jeg, $d u$, her, $n u$ ) henvises til elementer i den retoriske situation, som forudsættes at være kendt for tegntolkerne. Det gælder alle sproglige tekster, både mundtlige (som også har situationel forankring) og skriftlige (som kan have vilkårlig placering og kan interpreteres uafhængigt af situationen hvor den er produceret). Sproglige sætninger skal nemlig indeholde finitte verber der bøjes i deiktisk tid og har dermed eksplicit deiktisk forankring. Sproglige tegnenheder der ikke indeholder finitte verber, fx et enkeltstående nominal som titel på et maleri: Tordenskjold, har så ved sin faste placering implicit forudsat forankring til billedet. 
3. Eksplicit henvisning til relater til den retoriske situation. Tegngiveren kan forankre den retoriske situation ved konventionel henvisning til tider, steder, personer og begivenheder som står i et kendt forhold til den, dvs. ved datering, stedsbestemmelse og underskrift i breve, aviser, dagbøger og kolofoner på bøger.

4. Ingen forankring. I tegnsystemer hvor der ikke er tidsbøjede finitte verber (matematik, formel logik og noder) og i generiske sætninger, fx Loven er et rovdyr, hvor præsensformen ikke henviser til nutid, men til enhver tid, er der ingen forankring af meningen til den retoriske situation. Meningen er generisk, dvs. handler ikke om specifikke situationer, men om mulige situationer. Generisk mening er tautologisk i den forstand at meningen ikke siger mere end det der er defineret ved meningen med de elementer der indgår i den. Generisk mening er en slags normering af hvordan man i den retoriske situation i det hele taget kan kommunikere om den fremstillede situation.

5. Forankring på skrømt. Det sker fx i jeg-romaner og noveller, hvor det er tegngiverens intention at deiksis ikke fungerer. Klaus Rifbjergs roman Operaelskeren begynder fx således: 21-2:

"Jeg ved godt, hvad der driver mig til dette, selv om jeg ikke forstår mig selv. Se på ordet forstår."

Det ser ud som en dagbog hvor deiksis ikke fungerer (der er ikke noget årstal og nogen underskrift). Men samtidig er der på forsiden forfatternavn og bogtitel, og i kolofonen står der (C) Klaus Rifbjerg 1966. Så de deiktiske ord er bevidst ikke til at tolke for læserne, og det falder ind under overgenren skønlitteratur.

\section{Matematik og logik er uforankret og generisk}

Grunden til at matematik og formel logik ikke har deiksis er, som beskrevet ovenfor, ikke at de er enkeltartikulerede tegnsystemer, men for det første at de er tegnsystemer der er født visuelle, og uden fast placering ikke er situationelt forankret. Eksplicit deiksis ville altså ikke kunne give mening i sådanne systemer. 
Men for det andet er matematik og prædikatslogik formelle sprog der ikke er opstået som middel til kommunikation og ikke skal meddele information om noget andet end om systemet selv. De er aksiomatiske systemer der alene defineres ved syntaks, nemlig ved et sæt udefinerede aksiomer (grundsætninger) og nogle regler med hvilke man kan aflede teoremer af aksiomerne (Hofstadter 1979). Hvis teoremerne kan produceres på grundlag af aksiomerne efter reglerne, kan de tilskrives mening efter samme ordbog som aksiomerne. Systemet sikrer sandhedskonstans. Semantikken tilordnes hver enkelt mindsteenhed i en en-til-en-ordbog og det udelukker homonymi. Et konstrueret tegnsystem genererer fx følgende teorem som derved er bevist:

\section{(4) $25 \bullet 9 \square 16$}

Man kan nu tillægge elementerne i dette system forskellige betydninger af tegnene $\bullet$ og $\mathbf{\square}$. Enten betyder $\bullet$ minus, og $\boldsymbol{\square}$ lig med, eller også betyder - lig med og $\mathbf{\square}$ plus:

(5) $25-9=16$

(6) $25=9+16$

I begge semantikker er teoremerne sande fordi aksiomerne og produktionsreglerne (som ikke er vist her) udgør et konsistent system. Formelle sprog er således defineret ved syntaks, mens naturlige sprog først og fremmest skal kommunikere semantik, og det ved hjælp af syntaks. Så matematik og prædikatslogik handler slet ikke om hvad tegnene henviser til, men kun om sandhedskonstans mellem sætninger. Og eftersom deiksis handler om hvad tegnene henviser til, er der slet ikke plads til deiksis i formelle systemer.

For det tredje er de semantikker man tilordner de matematiske og logiske syntaktiske systemer, altid generiske, dvs. viser hvilke udsagn der er sande per definition og i grunden er tautologiske. Der bliver aldrig i disse systemer henvist specifikt til individer, men kun til vilkårlige elementer i klasser af individer, det som i logikken kaldes variable. Meningen med tegn, fx $\bullet$ og $\boldsymbol{\square}$, er det som defineres ved aksiomerne og slutningsreglerne, så det er sandt per definition at $25-9=16$. Der er ingen informationer i denne ligning andre end konsekvenserne af definitionerne.

Det betyder endvidere at formelle tegnsystemer alene hviler på princippet om kompositionalitet, dvs. at meningen med en helhed er lig med meningen 
med delene og meningen med måden de er kombineret på. Naturlige sprog er derudover styret af princippet om funktionalitet, dvs. at meningen med en del er bestemt af dens funktion i helheden. Det samme formelement kan have forskellige betydninger $\mathrm{i}$ forskellige funktioner, hvad man fx ser $\mathrm{i}$ homonymer: en ret linser, Riber Ret, den er ret stor, ret ind. Deiksis kan betragtes som en form for homonymi og kan ikke forekomme i formelle sprog der alene hviler på kompositionalitet. De deiktiske størrelser jeg og $d u$ _betyder to forskellige ting i denne ene sætning: Z Jeg hørte at du sagde: "Zeg forventer at du kommer".

\section{Naturlige sprog har fire typer af mening}

Resultatet af undersøgelsen af forholdet mellem enkelt- og dobbeltartikulerede tegnsystemer, eksplicit konventionel deiksis og situationel forankring kan sammenfattes i følgende skema:

(7)

\begin{tabular}{|l|l|l|l|l|}
\hline \multicolumn{2}{|c|}{ auditiv } & \multicolumn{2}{|c|}{ Visuel } \\
\hline \multicolumn{2}{|c|}{ formen udgør et forløb i tid } & \multicolumn{2}{|c|}{ formen forløber ikke i tid, men skal evt. tolkes i tid } \\
\hline \multicolumn{2}{|c|}{$\begin{array}{l}\text { fast placering af formen: den fremstillede situation er forankret i } \\
\text { tegntolkernes tid og rum }\end{array}$} & \multicolumn{2}{|c|}{$\begin{array}{l}\text { vilkårlig placering: } \\
\text { uforankret mening }\end{array}$} \\
\hline $\begin{array}{l}\text { TALE: Eksplicit } \\
\text { deiksis fungerer }\end{array}$ & $\begin{array}{l}\text { GESTUS: Eksplicit } \\
\text { deiksis (pegning) } \\
\text { fungerer }\end{array}$ & $\begin{array}{l}\text { PIKTOGRAM: Ingen } \\
\text { eksplicit deiksis }\end{array}$ & $\begin{array}{l}\text { SKRIFT: Eksplicit } \\
\text { deiksis fungerer ikke }\end{array}$ & $\begin{array}{l}\text { MATEMATIK, LOGIK, } \\
\text { NODER: ingen deiksis }\end{array}$ \\
\hline $\begin{array}{l}\text { gene- } \\
\text { risk }\end{array}$ & \multicolumn{5}{|c|}{ specifik henvisning } & $\begin{array}{l}\text { specifik og generisk } \\
\text { henvisning }\end{array}$ & generisk henvisning \\
\hline
\end{tabular}

De forskellige tegnsystemer: tale, gestus, piktogrammer, skrift, matematik, logik og noder, adskiller sig på en række parametre: om de er auditive eller visuelle, om formen udgøres af et forløb i tid eller er stabil (selv om den som skrift skal tolkes i tid), om tegnenes form er fast placeret i tid og rum eller vilkårligt placeret, og om tegnenes henvisninger er specifikke, generiske, eller med mulighed for begge dele. Disse egenskaber ved tegnsystemerne er definerende for at systemerne tale og gestus har eksplicitte og konventionelle deiksisformer (hhv. deiktiske ord som jeg, du, her, nu og pegning), at trafikskilte ingen eksplicit deiksis har, at deiksis i skrift uden anden forankring af meddelelsen ikke giver mening, således at matematik, logik og noder ikke har eksplicit deiksis, og at meningen med disse tegnsystemer ikke er forankret til en specifik situation, men altid er generiske. 
Brugen af konventionelle tegn indebærer, i modsætning til brugen af rent analoge billedtegn, artikulation, dvs. tegn der er leddelte både i koden (paradigmatisk) og i kæden (syntagmatisk). De er valgt ud af et inventar af mindstetegn (morfemer), og de kan kombineres, dvs. at mindre enheder på et lavere niveau i komposition udgør konstituenter af større enheder på et højere niveau. Der er på alle niveauer korrespondens mellem formen på et niveau og en bestemt type af mening: Formens niveauer er morfemer (og ord), sætninger, tekster og handlinger, og de svarer til hhv. konceptuel, propositionel, informationel og interaktionel mening.

Morfem- og ordlaget med leksikalske morfemer har konceptuel eller generisk mening; syntakslaget med grammatiske morfemer og ordstilling i sætninger har propositionel eller logisk mening med sandhedsværdi; på tekstlaget hvor flere sætninger er sat sammen til en helhed, er nogle informationer sat i baggrunden og et informationelt fokuseret budskab sat i forgrunden, og på handlingslaget udgør tegnet sociale handlinger mellem de specifikke og virkelige kommunikationsparter. Lagene svarer til de underdiscipliner som har udviklet sig i sprogvidenskaben: leksikalsk semantik, morfologi, syntaks og logik, tekstlingvistik med relevans-teori og pragmatik med talehandlingslære.

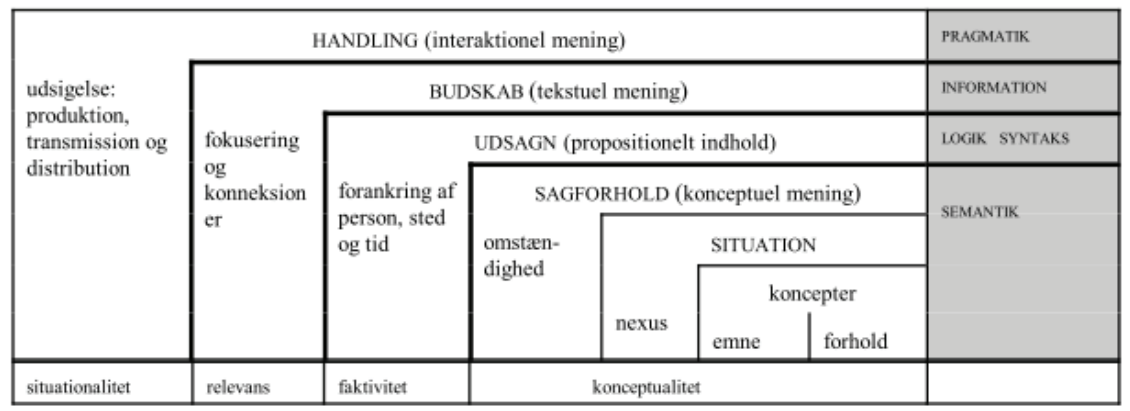

Det særlige ved de fire forskellige typer af mening er at de ydre typer er metakommunikation om de indre typer, som det fremgår af følgende løgmodel (Togeby 2003): 
(9)

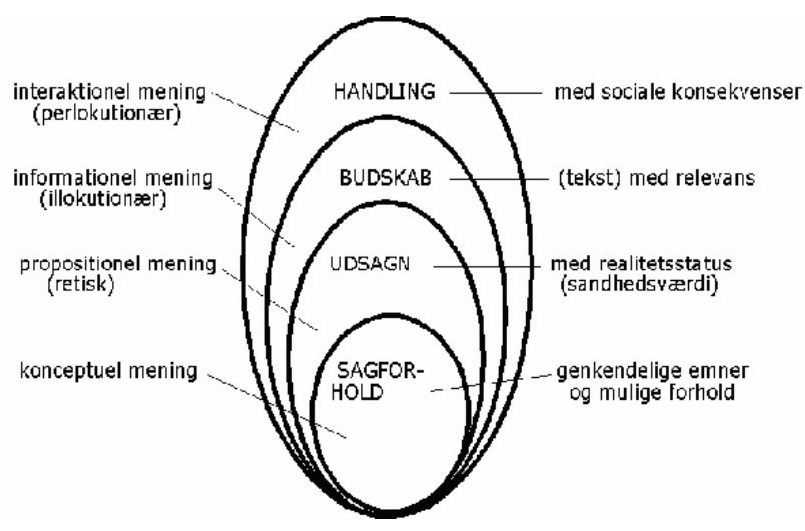

På alle fire lag kan der skelnes mellem elementer der er typer, og som er defineret funktionelt ved de forskelle (i formen) som gør en forskel (i meningen), og elementer der som eksemplarer er varianter af typerne, varianter som tegnbrugerne ser bort fra fordi de ikke giver mening - i det valgte tegnsystem. Typerne er defineret og afgrænset på forskellig måde for hvert lag: morfemer som det der er resultatet af kommutationsprøven (Hjelmslev 1966); sætninger som det der passerer acceptabilitetsprøven, og som kan genereres af en formel syntaks (Chomsky 1957); ytringer (tekster) som det som er intenderet med refleksiv intention om et relevant budskab til tegntolkerne om en sag (Grice 1975); kommunikative handlinger som er styret af konstituerende regler for social interaktion (i modsætning til af regulerende regler for hvordan tekster fokuseres på budskabet, Searle 1969).

Fænomenet deiksis hører til på to forskellige planer, nemlig både på det propositionelle plan idet der med deiksis udpeges identificerbare elementer i den fremstillede verden, men samtidig på det interaktionelle plan fordi elementer fra den retoriske situation indgår som elementer i den fremstillede situation; tegnet handler altid bl.a. om de kommunikerende parter (ofte som regulerende handling).

At matematik, formel logik og nodeskrift ikke har deiksis, skyldes således (ikke at disse tegnsystemer er enkeltartikulerede, men) 1. at de er født grafiske, og at tegnenes former ikke har nogen fast konventionel placering, 2. at matematik og prædikatslogik ikke er naturlige sprog, men formelle sprog som er defineret alene ved syntaks som så kan tildeles en af flere mulige semantiske tolkninger, og 3. at de kun kan tildeles semantik på en dimension af mening, mens naturlige sprog har en multidimensional semantik. 


\section{Henvisninger}

Chomsky, N. (1957): Syntactic Structures. The Hague: Mouton.

Foster, E.P. (1908): Ro. Cincinnatti: The Ro Company.

Foster, E.P. (1910): Ro, an international language based on the classification of ideas. Cincinnati: The Ro Company.

Grice, H.P. (1957): Meaning. Philosophical Review 66, 377-88.

Grice, H.P. (1975): Logic and Conversation. I: Syntax and Semantics, vol. 3. Speech Acts. Cole, P. \& Morgan, J.(red.) New York: Academic Press. Hjelmslev, L. (1943, 1966): Omkring Sprogteoriens grundlaggelse. København: Akademisk Forlag.

Hofstadter, D.R. (1979): Gödel, Escher, Bach: An Eternal Golden Brand. New York: Vintage Books.

Jakobson, R. (1967): Closing statement: Linguistics and poetics. I: Style in Language. Seboek, T.A. (red.). Cambridge, Massachusetts: MIT Press. Optrykt og oversat af Wille, N.E. som Lingvistik og Poetik, i Vindrosen 14: 7. Peirce, C.S. (1994): Semiotik og pragmatisme. København: Samlerens Bogklub.

Searle, J.R. (1969): Speech Acts. Cambridge Massachusetts: Cambridge University Press.

Togeby, O. (2003): Fungerer denne satning? Funktionel dansk sproglare. København: Gads Forlag.

Togeby, O. (2014): Bland blot genrerne - ikke tekstarterne. København: Samfundslitteratur. Togeby O. (2015): Sprog og identitet. Skandinaviske Sprogstudier Argang 6: 3.

Togeby, O. (2016): Gaden er et hav af tegn: Lær at svømme! I: Gaden: estetisk, sprogligt, kulturelt. Gammelgaard, L., Hornbek, B.R., Jørgensen, H. \& Norup, L. (red.). Hellerup: Spring.

Tomasello, M. (2003): Constructing a language. A Usage-Based Theory of LanguageAcquition. Cambridge Massachusetts: Harvard University Press. 